\title{
Enforcement of labor regulations and job flows: evidence from Brazilian cities
}

\author{
Ana Abras $^{1 *}$ (D), Rita K. Almeida ${ }^{2}$, Pedro Carneiro ${ }^{3}$ and Carlos Henrique L. Corseuil ${ }^{4}$
}

\author{
* Correspondence: \\ ana.abras@ufabc.edu.br \\ ${ }^{1}$ Universidade Federal do ABC, Rua \\ Arcturus 3, São Bernardo do \\ Campo, São Paulo 09606-070, Brazil \\ Full list of author information is \\ available at the end of the article
}

\begin{abstract}
The frequency of labor inspections in Brazil increased in the late 1990s. In the years that followed, between 2003 and 2007, formal employment expanded significantly in the country. This paper examines whether these city-level changes in labor inspections could be a significant factor contributing to the increase in the number of formal labor contracts at the city level. We exploit unique administrative data on formal employment on different indicators for job and worker flows-including job creation, destruction, reallocation, accessions, and separations-between 1996 and 2006, and on the intensity of labor inspections, both at the city level. The results show that increases in the enforcement of labor market regulations at the subnational level led to an increase in gross and net formal job creation rates and accession rates in a period when the Brazilian GDP and formal employment were growing and informality rates were declining. In contrast, increases in enforcement of regulations are not significantly correlated with changes in the rate of job destruction. This finding is robust to different specifications and is consistent with a model where formal jobs become more attractive to workers when enforcement of different types of labor regulations increases.

JEL Classification: J21, J63, E24, H80, C23
\end{abstract}

Keywords: Formal employment growth, Job flows, Enforcement labor market regulations, Panel data

\section{Introduction}

As more micro-level data becomes available, the understanding of labor market adjustment has benefited considerably from a literature looking into jobs or worker flows as the main outcome variables. ${ }^{1}$ This new approach has unveiled new results on labor market adjustments to changes in the environment such as business cycle fluctuations (Shimer 2012), or minimum wage shocks (Brochu and Green 2013). This paper looks at a shock that has been substantively overlooked: how labor markets in emerging economies react to changes in the enforcement of labor legislation. In spite of the importance of the topic, the literature has not been conclusive about the relation between enforcement of labor regulations and rates of job flow in emerging economies. ${ }^{2}$ On the one hand, enforcement of labor regulations increases (formal) labor costs and could lead to lower rates of formal job creation. On the other hand, enforcement can directly impact job creation though the regularization of informal jobs at the plant level.

(c) The Author(s). 2018 Open Access This article is distributed under the terms of the Creative Commons Attribution 4.0 International License (http://creativecommons.org/licenses/by/4.0/), which permits unrestricted use, distribution, and reproduction in any medium, provided you give appropriate credit to the original author(s) and the source, provide a link to the Creative Commons license, and indicate if changes were made. 
Moreover, higher compliance formal sector jobs can become more attractive to workers, lowering job destruction and separations.

This paper exploits unique Brazilian administrative data at the city level to answer this question. In particular, it exploits information on job and worker flows and administrative data on the enforcement of labor market regulations, captured by the incidence of labor inspections, across cities between 1996 and 2006. We measure enforcement of labor regulations using the frequency of labor inspections at the city level. During this period, Brazilians went through an important expansion in labor markets with employment growing $7 \%$ in the formal sector on average and average rates of job creation and job destruction of 15.4 and $8.6 \%$, respectively. Along with the increase in employment, the average annual GDP growth of $2.6 \%$ contributed to the decline in informality in the labor market from 54.9 to $51.5 \%{ }^{3}$ Simultaneously, during this period labor inspections on fundamental aspects of the de jure labor code, such as contributions to the job severance fund, also increased significantly. ${ }^{4}$

Simply relating labor regulations with aggregate indicators of job growth or job flows would, however, not be likely to yield a good estimate of the impact of enforcing labor regulation on job flows. The main empirical challenge lies in that enforcement of labor regulations is, in practice, not randomly distributed across all Brazilian cities. On one end, enforcement may be stronger in cities where reports of labor violations are more frequent as a significant part of inspections are triggered by anonymous reporting. On the other end, enforcement may be stronger in richer and larger cities, also with better institutions. Moreover, Brazilian firms likely faced other policy shocks, over this period, possibly affecting their patterns of jobs and workers flows. Two examples are the expansion of firms' business credit lines (Catão et al. 2009) and significant tax simplification programs for small businesses (Fajnzylber et al. 2011).

To mitigate this concern, we consider a simple reduced form equation exploiting time and within-country variation, across cities, in the enforcement of labor market regulations and in the rates of job creation and job destruction. In other words, our reduced form compares changes over time in the degree of enforcement of labor regulations at the city level and relates that variation to changes in job and worker flow rates. The advantage is that, by exploiting subnational variation, this reduced form accounts for any time varying nationwide shocks that could have simultaneously contributed to the increase in employment formality during this period. In addition, our data includes a robust set of time-varying observable characteristics at the city level (e.g., city GDP, the distribution of plant size, and the share of educated workers at plant level, total city population, and total city homicide rates). In addition, because we exploit city-level panel data, we can account also for unobservable city-year time trends.

Our findings suggest that, all else being constant, cities facing an increase in the enforcement of labor market regulations tend to have higher rates of worker flows in both margins: accessions and separations. Stringent enforcement is also related to increases in job creation rates. In contrast, changes in job destruction rates as measured in our administrative data set are not related with changes in the degree of enforcement of labor regulations. Our main findings are robust to the inclusion of state-level time trends, considering different sub-national samples.

The paper draws upon and contributes to different literatures. First, it relates to the literature analyzing, at an aggregate level, indicators of job growth/flows with country 
regulations and institutions. While earlier empirical cross-country work did not find a significant link between labor regulations and job reallocation (see Bertola and Rogerson 1997; Davis and Haltiwanger 1999), more recent findings show that, even after accounting for differences across countries in technology and sector composition, there is still sizeable unaccounted variation in job reallocation across countries. This unexplained variation can be related to institutional or policy variables or to measurement error inherent to cross-country studies (see Bartelsman et al. 2009). The literature looking at the institutional role in explaining this cross-country variation in job reallocation shows that labor regulations may play an important role.

Difference-in-difference estimations exploiting cross-country variation in the firing and hiring costs show a strong and negative relationship between restrictive regulation and the reallocation of resources (e.g., Micco and Pages 2004; Haltiwanger et al. 2010). Because our work explores within-county variation in the degree of enforcement of labor regulations, our empirical approach bypasses some of the measurement issues and assumptions in previous research by using time and within country variation in de facto regulation within a single country. As the enforcement of policies is not uniform across regions in Brazil, we discuss a tighter link between the degree of stringency of the de facto labor market regulations and job reallocation in cities under a similar institutional environment.

Secondly, it relates to the literature studying the impact of labor regulations on firm dynamics and labor market outcomes. The literature here is extensive and considers several dimensions of labor market regulations, from the compliance with mandated benefits (such as unemployment or health benefits) or the minimum wage to alternative employment protection measures. The theoretical predictions on how these regulations affect firm outcomes are diverse. While the literature on the effects of mandated benefits on labor market outcomes in developing countries has produced mixed results, ${ }^{5}$ the impacts of employment protection rules likely vary for different workers and firms. ${ }^{6}$ Because our empirical approach will explore variation in labor inspections, we are effectively considering the de facto enforcement of a diverse mix of labor policies. This has advantages and disadvantages relatively to comparing the variation in de jure regulations. While on the one hand, one cannot try to identify the effect of each regulation, on the other hand, any effect identified already considers the interactions of de facto regulations and of their enforcement, which is ultimately what impacts individuals.

Thirdly, we relate to the literature analyzing how changes in the enforcement of labor market regulations impacts labor market outcomes. This work was initiated by Almeida and Carneiro (2009) and proxied enforcement of labor regulations with the average labor inspections in the city. ${ }^{7}$ Almeida and Carneiro (2012) look at the impacts of enforcement of labor regulations on different labor market variables, also exploring administrative city-level data on labor inspections. Exploring only the within-country variation across cities, they show that, in response to a rise in labor inspections, there is an increase in formal employment, a decrease in informal employment, a rise in non-employment, a decline in wages at the top of the formal wage distribution, and an increase in informal wages. All of the movement from the informal to the formal sector is among the self-employed. There is little change in the employment and wages of those who are informal employees. Almeida and Carneiro (2012) argue that, in the early 1990s, labor inspectors started enforcing compliance with mandated benefits, 
namely contributions in advance to the job severance fund, and job severance payments upon dismissal. As a result of increased enforcement, formal workers support more generous mandated benefits by receiving lower wages. The value that workers place on these benefits is potentially higher than their cost to employers because they are untaxed. In addition, wage rigidity (e.g., through minimum wages) may prevent downward adjustment at the bottom of the wage distribution. This causes formal sector jobs at the bottom of the wage distribution to become more attractive to informal workers, leading them to switch to the formal sector.

Our work contributes to this literature by exploiting within-country and time series variation in the enforcement of labor market regulations between 1996 and 2006 and focusing now on job and worker flows, including indicators of job creation, job destruction, reallocation, accessions, and separations. In addition, our results are aligned with Almeida and Carneiro (2012) on how labor inspections are related to employment in the formal sector. There are different ways that labor inspections can affect job and worker flows, and the direction of the relationship is not clear a priori. On the one hand, inspections can directly impact job creation though the regularization of informal jobs at the plant level. Indirectly, with higher compliance, formal sector jobs can become more attractive to workers, lowering job destruction and separations. On the other hand, more inspections increase the cost of formal jobs and can lead establishments to shed workers. Almeida and Carneiro (2012) show that in cities with more frequent inspections, formal employment tends to be higher. This finding is fully consistent with our results of higher formal net employment growth and job creation rates in cities with more frequent inspections.

One fact is worth highlighting. Unlike Almeida and Carneiro (2012) who explore the Brazilian population census, our paper explores administrative data only on formally registered firms. It thus only captures the formal labor contracts and one cannot make any inferences about the relationship between inspections and the subsequent regularization of labor contracts as we do not observe informality.

This paper is organized as follows. Section 2 presents an overview of the main changes in the procedures of labor inspection implemented in Brazil, arguing that changes in these policies have made them more effective. Section 3 discusses the data used and indicators computed. Section 4 presents the empirical methodology and the proposed reduced form. Section 5 reports the main descriptive statistics for the final sample, and Section 6 discusses the empirical results. Section 7 discusses conclusions and main policy implications.

\section{Labor inspections in Brazil}

Starting in 1995, the Ministry of Labor and Employment (MTE), under the Secretary of Work Inspection (SIT), implemented a series of reforms aiming to increase the efficiency of inspections. ${ }^{8}$ The reform emphasized a new way of monitoring outcomes of labor inspections (see Miguel 2004). The primary objective was the standardization of the results of labor inspections at the national level. The creation of the Federal System of Labor Inspection (SFIT) was an important tool for this aim. First, the system allowed the creation of a routine to plan labor inspections throughout the country. Schedules with the targeted outcomes (goals) began to be sent annually by various Regional Offices of Labor to create a system of inspections. This reform made policies less 
reactive to complaints about labor standards and more proactive and based on long-term planning. In addition, the reform developed financial incentives so that labor inspections played became more efficient. The system awarded bonuses linked to performance. The bonuses were granted in accordance with the enforcement goals initially established. These goals generally considered the number of inspected plants and the total financial amount collected from fines. It is worth noting that the bonus system is not the only incentive mechanism. Pires (2011) argues that the formation of regional and sector teams with common goals is an additional incentive mechanism to individual bonuses. ${ }^{9}$

The reform also involved the change in the motivation of labor inspections. Miguel (2004) states that "the main objective was to make inspection less punitive and more educational, thus making it more effective from a social-economic point of view". In this context, it is important to highlight two actions: (i) the creation in 1996 of handbook entitled "Mediator's Manual" which contained advice to resolve labor conflicts, and (ii) the increase of available options for the labor inspector, beginning in 2001, when "tables of understanding" were permitted to debate solutions over difficult-to-solve irregularities during audit visits. Pires (2008) suggests that this new approach contributed to enabling the labor inspector to fulfill his role in a more efficient manner. Almeida (2008) also explores this point, arguing that this type of strategy is particularly successful in nonmetropolitan areas cities that agglomerate small businesses. ${ }^{10}$

Therefore, since 1995, the inspector (i) became more oriented on the focus of their actions, (ii) received more incentives to work more intensively perusing evasion (with pay for performance schemes), and (iii) had more resources to support any irregularities found. We argue that these changes in labor inspections in Brazil were accompanied by an improvement in the inspection-related indicators. Table 1 illustrates this point.

Column (1) of Table 1 displays the annual growth in the rate of formalization of workers following inspections which is captured by the number of workers registered during labor inspections divided by the number of workers covered by these same inspections. This ratio increases from $1.8 \%$ in $1996-2000$ to $2.6 \%$ in $2001-2006$. Column (2) shows that in these two periods, the annual average number of plants inspected by each inspector decreased from over 141 to less than 120. Therefore, an increase in the rate of formalization seems to have been motivated by better and more targeted inspections rather than by more inspections.

This hypothesis is indirectly supported in the third column, which shows that the mean size (captured by total number of employees) of the inspected plant increased by almost $50 \%$, changing from 50 to $74 .{ }^{11}$ If we consider that informal labor contracts are

Table 1 Country means for labor inspection variables, 1996-2000 and 2001-2006

\begin{tabular}{lccccc}
\hline Year & $\begin{array}{c}\text { Rate of formalization } \\
\text { following inspections (\%) }\end{array}$ & $\begin{array}{c}\text { Number of } \\
\text { inspected plants } \\
\text { by labor inspector }\end{array}$ & $\begin{array}{c}\text { Size of } \\
\text { inspected } \\
\text { plants }\end{array}$ & $\begin{array}{c}\text { Plants } \\
\text { with labor } \\
\text { fines (\%) }\end{array}$ & $\begin{array}{c}\text { Fines per } \\
\text { plant }\end{array}$ \\
\hline Av. 1996-2000 & $(1)$ & $(2)$ & $(3)$ & $(4)$ & $(5)$ \\
Av. 2001-2006 & 1.8 & 141.4 & 50 & 18.3 & 1.6 \\
\hline
\end{tabular}

Source: Authors' calculations using RAIS, Ipeadata, and Ministry of Labor-SFIT administrative data on inspections (1996-2006) Note: Sample size includes 5654 cities and 32,553 obs across the two periods 1996-2000 and 2001-2006. In column (1), rate of formalization following inspections implies that on average 1.8 of the employees being formalized after inspection. In column (2), the number of inspected firms by inspector in the period. In column (3), the number of employees in inspected firms. In column (4), the percent of firms that received a fine. In column (5), the number of times a firm was fined 
less frequent in larger plants, then an increase in the mean size of inspected plants may be related to a decrease in the rate of labor contracts that become registered because of the inspections. Nevertheless, the first column of Table 1 indicates an increase in the rate of contracts registered following the labor inspections. These facts are reconciled if, throughout this period, there is an increase in the effectiveness of inspections.

Finally, the last column of Table 1 shows that the percentage of inspected plants which have been fined remained stable at around 18\%. This suggests that the highest rate of formalization was not the result of applying harsher penalties. ${ }^{12}$ That is an indication that the improvement of labor inspection, with respect to combating informality, is due to a more effective performance on the part of the labor inspector. ${ }^{13}$ Table 2 shows the inspection intensity measured at the city level and used in the regression analysis: number of visits over the number of plants. This indicator is stable from 1996 to 2006, with small dips in 1998 and 2004.

Note that this increased effectiveness of labor inspections could have come from any combination of the three dimensions outlined above. Identifying the specific contributions of each of these dimensions is beyond the scope of this work.

Another change in labor inspection in Brazil occurred outside the SIT. Since 1998, the Public Ministry of Work (MPT) began to play an active role in labor inspection, increasingly acting in parallel to the SIT. The most noteworthy fact is that in the last decade, five priorities were chosen for the SIT, one of them being the regularization of labor contracts. One should also take the performance of the MPT into account in the analysis. However, because we lack information about MPT's results, we will focus the analysis on labor inspection under the SIT.

\section{Data and indicators}

In the empirical work, we will explore different data sets covering the period between 1996 and 2006. First, we explore the report on social information RAIS (Relação Anual de Informações Sociais, RAIS) (see Appendix for correspondence between RAIS and SFIT data), published yearly by the Brazilian Ministry of Labor and Employment, and capturing all the sectors of the economy (agriculture, industry and services). ${ }^{14}$ This is our source of information to compute measures of job and worker flows. We consider the total number of accessions $\left(A_{i, t}\right)$ and separations $\left(S_{i, t}\right)$ each year (denoted with subscript $t$ ) in every formal plant. ${ }^{15}$ Those registered with the tax authority are denoted with subscript $i$. We compute net employment growth in each establishment $\left(\Delta n_{i, t}\right)$ which are the basic inputs for job flow measures.

Table 2 Inspection intensity by year

\begin{tabular}{lc}
\hline Year & Inspection frequency \\
\hline 1996 & 0.22 \\
1998 & 0.18 \\
2000 & 0.22 \\
2002 & 0.19 \\
2004 & 0.17 \\
2006 & 0.20 \\
\hline
\end{tabular}

Source: Authors' calculations using RAIS and SFIT 1996-2006

Note: inspection frequency is measured at the city-level by the number of visits divided by the average number of establishments in the city 
We also compute job and worker flow measures aggregated at the city level between 1996 and 2006. Job creation and destruction rates at the city level (denoted by subscript $j$ ) are defined as in Davis et al. (1996):

$$
\begin{aligned}
& J C_{j, t}=100^{*}\left[\sum_{\mathrm{i} \in j}\left(\Delta n_{i, t}\right) \cdot I\left(\Delta n_{i, t}>0\right) / N_{j, t}\right], \\
& J D_{j, t}=100^{*}\left[\sum_{\mathrm{i} i j}\left|\Delta, n_{i, t}\right| . I\left(\Delta n_{i, t} \leq 0\right) / N_{j, t}\right],
\end{aligned}
$$

$J C_{j, t}$ and $J D_{j, t}$ denote the rate of job creation and destruction for year $t$ and city $j$, respectively. The two job flow rates are based on the change in employment resulting from the contrast of accessions and separations $\left(\Delta n_{i, t}\right)$ at the plant level $i$, in each city $j$ from years $t-1$ and $t$. When this variation is positive, it will contribute to job creation in the city, and when it is negative, it contributes to job destruction in the city. This condition appears in the above formulas through the indicator function $I(.) . N_{j}$ denotes the city average employment in 12 consecutive months during year $t$, and it is used for normalization of both rates.

Two job flow variables derived from job creation and destruction rates are also considered in the analysis: net job growth rate and job reallocation rate. These measures allow us to look at distinct aspects of labor market, namely the net increase in job positions and the increase in job churning. It is possible that the policy studied has no effect in employment growth at city level but increases job reallocation within cities through job creation and job destruction at distinct plants within the same city simultaneously. For instance, jobs may flow from plants with higher inspection probability to plants with lower probability of being inspected.

$$
\begin{aligned}
& N E T_{j, t}=J C_{j, t}-J D_{j, t} \\
& R E A L L_{j, t}=J C_{j, t}+J D_{j, t}
\end{aligned}
$$

Finally, we also aggregate accessions and separations at city-level computing:

$$
\begin{aligned}
& A_{j, t}=100^{*} \sum_{\mathrm{i} \epsilon j}\left(\mathrm{~A}_{i, t}\right) / N_{j, t} \\
& S_{j, t}=100^{*} \sum_{\mathrm{i} \epsilon j}\left(\mathrm{~S}_{i, t}\right) / N_{j, t}
\end{aligned}
$$

where $A_{i, t}$ and $S_{i, t}$ are accessions and separations of workers at the plant level, as previously defined. Accessions are the sum of hires $(H)$, rehires $(R H)$, and transfers from other establishments in the same firm. Separations are sum of quits $(Q)$, fires $(F)$, discharges $(D)$, and transfers $(T O)$ to other establishments in the firm. The average employment in the 12 consecutive months during year $t$ is used for normalizing both rates. Using the RAIS data, it is possible to identify month-to-month changes in employment and the average employment within the year. The upside of this approach is that we avoid possible autocorrelation introduced in the regression by defining variables with previous year's information.

Second, we explore annual information on labor inspections at the city level. This is collected by the Brazilian Federal System of Labor Inspection (SFIT) which is part of 
the Ministry of Labor. The data is available at the city level for the years 1996, 1998, 2000, 2002, 2004, and 2006. Our period for the analysis coincides with these years since this is the most restrictive set of data in the time dimension. We measure labor inspections in the city $j$ with an indicator of the average frequency of total labor inspections per plant in the city, where the number of plants in each city is computed using RAIS:

$$
F R_{j, t}=\mathrm{LI}_{j, t} / \sum_{\mathrm{i}}(I(\mathrm{i} \varepsilon j))
$$

where $L I_{j, t}$ is the total amount of visits by labor inspectors in city $j$ during year $t$ and $I_{(i e j)}$ is the same indicator function used before.

Third, we use additional variables to control for differences across cities/years such as yearly and city-level GDP, current city government expenses as a fraction of GDP, agricultural sector GDP, service sector GDP, population, and the number of homicides. GDP-related information was taken from IPEADATA, while population and homicides information are available at DataSUS. ${ }^{16}$

\section{Empirical methodology}

We consider a simple reduced form equation relating the different measures of job flow and job reallocation with enforcement of labor regulations, measured by labor inspections. As described in the previous section, we consider different dependent variables of interest: total job creation and destruction rates $(J C$ and $J D)$, net job growth (NET, equal to $J C$ minus $J D$ ), reallocation rate $(R E A L L$, equal to $J C$ plus $J D)$, accession rate $(A)$, and separation rate $(S)$.

$$
Y_{j t}=\beta \mathrm{FR}_{j t}+\gamma X_{j t}+\mu_{t}+\alpha_{j}+\varepsilon_{j t}
$$

where $Y_{j t}$ denotes the value of the dependent variable of interest, in city $j$, and year $t$, and where $t=1996,1998,2000,2002,2004$, and 2006; $\mathrm{FR}_{\mathrm{jt}}$ captures the frequency of labor inspections in city $j$ at year $t$; and $X_{j t}$ captures time-varying city-level characteristics such as the average, median, and 75th percentile of plant size in the city; city-level GDP; share establishments in agriculture; share of establishments in industry, average, median, and 75th percentile for the share of workers with secondary education in the establishment at the city-level; total city population; and total city homicide rates. The time variant city-level dummy variables account for city characteristics that may simultaneously affect job and worker flow measures and that could be related with the intensity of labor inspections at the city level. $\mu_{t}$ are year dummies to capture macro shocks; $\alpha_{j}$ are city dummies capture unobserved time invariant city-level characteristics; and $\varepsilon$ captures unobservable shocks to our dependent variable of interest. We estimate Eq. (8) using weighted ordinary least squares where the employment at city level is used as weight.

We will also test the robustness of the results by including in Eq. (8) state-level time trends, possibly correlated with city-level trends in the enforcement of labor regulations and with trends in job flow rates. Hence, we will estimate the following specification:

$$
Y_{j t}=\beta \mathrm{FR}_{j t}+\gamma X_{j t}+\mu_{t}+\theta_{s t}+\alpha_{j}+\varepsilon_{j t}
$$

where all the notation is as above and $\theta_{s t}$ captures the state specific trends. 


\section{Descriptive statistics}

Tables 3 and 4 report the evolution of our main dependent variables of interest at the aggregate level, between 1996 and 2006. Aggregation from city level to national level uses average city-year employment level as weights analogous to the use of average plant employment in (3). Table 3 shows that throughout this period, there have been an increase in average job creation rates and a decrease in job destruction. Column (1) shows that JC rises from $14.9 \%$ in 1996 to $18.1 \%$ in 2000 and then stabilizes around 17\%. Column (2) suggests a noisier evolution for JD, but with two distinct levels-a higher one in the 1990's (around 10\%) and a lower one in the 2000's (around 8.5\%). Columns (3) and (4) show that the net job growth increased substantially, while reallocation rates stayed approximately constant. The difference in the time patterns across measures in Table 3 highlights that each captures a distinct feature of the labor market, justifying their simultaneous use in the empirical work. The same can be said about using worker flow measures as a complement for job flow measures.

Table 4 presents the evolution of worker flows between 1996 and 2006. Column (1) reports accession rates which have increased substantially, especially in the 2000's, when JC was relatively stable. Separation rates, in column (2), display a U-shape varying from just above $40 \%$ in 1996 to its lowest value of $37.2 \%$ in 2000. Again, this contrasts with the JD evolution which was stable. It is interesting to note that worker flow rates are on average higher than job flow rates in the data. Although this should be the case since workers can move over and above the shifts in jobs, the difference between the two rates is substantial. In the US economy, where worker and firms may be the most unencumbered from moving, hiring, and separation rates in 2010 stood at only 18.7 and $18.5 \%$, respectively (Hyatt and Spletzer 2013).

In addition to the time series variation, our identification strategy will rely on the variation across cities in these indicators. Table 5 reports the within-country crosssectional variation in the main outcomes of interest for measures of job and worker flows and for the inspection intensity. The ratio between the 90th and 10th percentiles in job creation reaches almost 2 and passes this mark in job destruction. The analogous ratio for both worker flow measures are also higher than 2 .

Table 3 Job flows, 1996-2006

\begin{tabular}{lcccc}
\hline Year & Job creation rate & Job destruction rate & Net job growth rate & \multicolumn{2}{c}{ Job reallocation rate } \\
\hline 1996 & $(1)$ & $(2)$ & $(3)$ & 24.9 \\
1998 & 14.9 & 10.0 & 4.9 & 26.2 \\
2000 & 16.1 & 10.2 & 5.9 & 26.6 \\
2002 & 18.1 & 8.5 & 9.5 & 25.6 \\
2004 & 16.7 & 8.9 & 9.8 & 25.5 \\
2006 & 17.3 & 8.1 & 8.2 & 25.3 \\
$1996-2006$ Average & 16.9 & 8.5 & 7.0 & 24.3 \\
\hline
\end{tabular}

Source: Authors' calculation based on RAIS (1996-2006)

Note: all statistics are based on a sample of 5654 cities in each year. Column (1) reports average job creation in Brazil, column (2) reports job destruction, column (3) reports Net growth (job creation minus job destruction), and column (4) reports job reallocation (job creation plus job destruction). The statistic 14.6 for 1996 implies that job creation rate in Brazil over the period analyzed was $14.6 \%$ of the average total employment. Summary statistics in the last line report the average across all city-year cells. All values are weighted by year-employment size 
Table 4 Worker flows, 1996-2006

\begin{tabular}{lcc}
\hline Year & Accession rate & Separation rate \\
\hline 1996 & $(1)$ & $(2)$ \\
1998 & 45.5 & 40.6 \\
2000 & 44.2 & 38.3 \\
2002 & 46.8 & 37.2 \\
2004 & 46.6 & 38.8 \\
2006 & 47.9 & 38.7 \\
$1996-2006$ Average & 48.7 & 40.3 \\
\hline
\end{tabular}

Source: Authors' calculation based on RAIS (1996-2006)

Note: all statistics are based on a sample of 5654 cities in each year. Column (1) reports accession rate and column (2) reports separation rate. Summary statistics in the last line report the average across all city-year cells. All values are weighted by year-employment size

Table 5 reports substantial variation in the distribution for inspection intensity in our sample. The 10th and 90th percentiles go from less than 0.10 to 0.36 . Almeida (2008) suggests that the logistics of labor inspection vary significantly by the size of the city and the size of its establishments. The cross-sectional variation in the main variables of our analysis related to job and worker flows may be driven by city characteristics. This suggests that accounting for city differences helps to isolate part of confounding effects that might jeopardize the interpretation of our estimates in a univariate regression analysis.

Table 6 reports the intensity in labor inspections, between 1996 and 2006, depending on the firm and city size (we differentiate cities with more than 1000 establishments, cities with 100-1000 establishments, and cities with less than 100 establishments). Results show that inspection intensity is higher among larger firms (with more than 20 employees) and in larger cities (with more than 1000 establishments).

Figure 1 shows the average inspection intensity indicator at city level aggregated by selected states in different regions. Results show sizeable spatial and temporal variation in inspection intensity across the sample. Lastly, Table 7 reports summary statistics for the main control variables.

Table 5 Statistics for worker and job flows, inspection indicator, and establishment characteristics at the city level

\begin{tabular}{lcccc}
\hline & $\begin{array}{c}\text { Median } \\
(1)\end{array}$ & $\begin{array}{c}\text { Percentile } 90 \\
(2)\end{array}$ & $\begin{array}{c}\text { Percentile 10 } \\
(3)\end{array}$ & $\begin{array}{c}\text { Coeff. Var. } \\
(4)\end{array}$ \\
\hline Job creation rate & 15.4 & 22.9 & 11.8 & 0.4 \\
Job destruction rate & 8.6 & 12.6 & 5.5 & 0.4 \\
Net job growth rate & 7.0 & 13.6 & 2.2 & 0.9 \\
Job reallocation rate & 24.3 & 33.6 & 18.9 & 0.3 \\
Accession rate & 42.4 & 64.6 & 31.3 & 0.4 \\
Separation rate & 37.1 & 54.5 & 24.3 & 0.4 \\
Inspection frequency & 0.20 & 0.36 & 0.04 & 0.8 \\
\hline
\end{tabular}

Source: Authors' calculations using RAIS and SFIT (1996-2006)

Note: inspection frequency is measured at the city-level by the number of visits divided by the average number of establishments. Job creation, job destruction, net growth, job reallocation, accessions and separations are defined by Eqs. 1 to 6 in the main text, respectively. Column (4) has the coefficient of variation defined as the ratio of the standard deviation over the mean. Establishment size is defined as the number of employees divided by the number of establishments. Establishment size and share of workers with secondary degree are averaged across establishments in the city and aggregated at the national level using city-year employment weights 
Table 6 Inspection intensity, by average plant and city size

\begin{tabular}{lccccc}
\hline \multicolumn{5}{c}{ Panel A: establishment size (average number of employees) } \\
Size class & 1 to 4 & 5 to 9 & 10 to 19 & 20 to 49 & $50+$ \\
Inspection frequency & 0.05 & 0.11 & 0.19 & 0.32 & 0.20 \\
City size & \multicolumn{2}{c}{ Panel B: city size (number of establishments) } & & Small \\
Inspection frequency & \multicolumn{2}{c}{ Large } & Medium & 0.11 \\
\hline
\end{tabular}

Source: Authors' calculations using RAIS and SFIT 1996-2006

Note: Inspection Frequency is measured at the city-level by the number of visits divided by average number of establishments in the city. Establishment size is defined as the number of employees divided by the average number of establishments. Large, medium and small cities have more than 1000 establishments, between 100 and 1000 establishments, and less than 100 establishments

\section{Main findings}

The results of estimating Eq. (8) by ordinary least squares are reported in columns (1) through (6) of Table 8 for job creation and destruction rates, net job creation, job reallocation, accessions, and separations, respectively. Panel A does not control city-level time-varying characteristics $\left(X_{j t}\right)$ while panel B includes all the city time-varying characteristics reported in Table 8. The findings reported in column (1) to (4) of panel A show no significant relation between enforcement intensity and average city-level job flow rates. But the findings in the last two columns of panel A of Table 8 show that an increase in the enforcement of labor market regulations, as captured by increased number of inspections per plant, is correlated with increased rates of worker flows in the city. The results in panel A of Table 8 show that a one standard deviation increase in inspection intensity is associated with a 0.79 percentage points increase in accessions rates and with a 0.55 percentage points increase in separations rates.

In panel $\mathrm{B}$ of Table 8 , we control for several city-level time variant characteristics to account for the fact that labor and product market conditions at the city-level likely change over time. The results reported in columns (5) and (6) show that the main finding for worker flows holds; furthermore, in this reduced form, there is a substantive positive correlation between the intensity of labor inspections and the level of gross and net job creation at the city level. In particular, in cities with more frequent labor inspections, there are statistically significant higher city-level rates of job creation, net

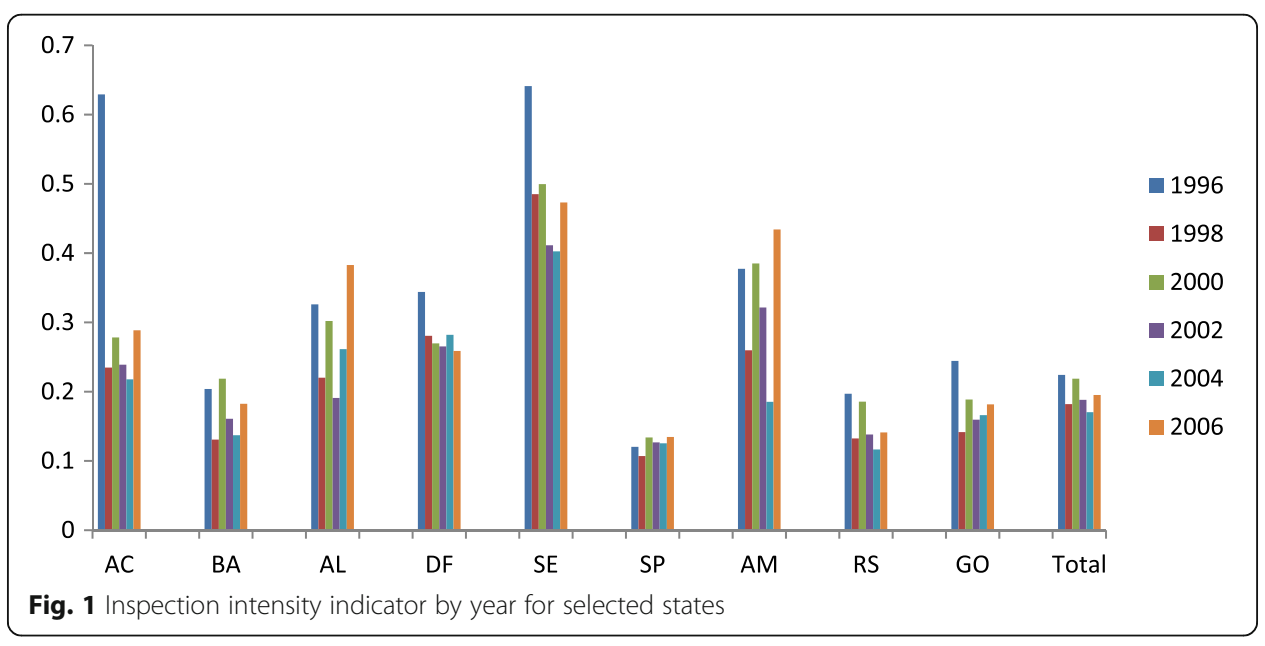


Table 7 Summary statistics for all city-level time-varying control variables

\begin{tabular}{lc}
\hline Average establishment size & 15.3 \\
Percentile (75th) of establishment size & 6.6 \\
Median of establishment size & 2.5 \\
Av. city GDP (R\$ thousand) & $27,282,547$ \\
Share of workers with secondary education & 0.34 \\
Percentile (75th) share of workers with secondary education & 0.64 \\
Median of share of workers with secondary education & 0.21 \\
Share of establishments in agriculture & $7.7 \%$ \\
Share of establishments in industry & $10.8 \%$ \\
Av. city population & $2,131,696$ \\
City homicide rate & 1.025
\end{tabular}

Source: RAIS and IPEADATA Sample 1996-2006

Note: table reports the summary statistics (means) for the whole sample across years 1996-2006. GDP is measured in year 2000 R\$ (thousand). Homicide measured as number per 100,000 persons

Table 8 Enforcement of labor Regulations and job flow rates

\begin{tabular}{|c|c|c|c|c|c|c|}
\hline $\begin{array}{l}\text { Dependent } \\
\text { variable }\end{array}$ & $\begin{array}{c}\text { Job creation } \\
\text { rate } \\
(1) \\
\end{array}$ & $\begin{array}{l}\text { Job destruction } \\
\text { rate } \\
\text { (2) }\end{array}$ & $\begin{array}{c}\text { Net job } \\
\text { growth rate } \\
\text { (3) }\end{array}$ & $\begin{array}{c}\text { Job reallocation } \\
\text { rate } \\
\text { (4) }\end{array}$ & $\begin{array}{c}\text { Accession } \\
\text { rate } \\
(5) \\
\end{array}$ & $\begin{array}{c}\text { Separation } \\
\text { rate } \\
(6) \\
\end{array}$ \\
\hline \multicolumn{7}{|c|}{ Panel A: no city-level time variant controls } \\
\hline $\begin{array}{l}\text { Enforcement } \\
\text { labor regulations } \\
\text { in city-year }\end{array}$ & $\begin{array}{c}1.2100 \\
(1.0433)\end{array}$ & $\begin{array}{l}-0.2557 \\
(0.7362)\end{array}$ & $\begin{array}{c}1.4656 \\
(0.9224)\end{array}$ & $\begin{array}{c}0.9543 \\
(1.5525)\end{array}$ & $\begin{array}{l}4.8572^{*} \\
(2.0247)\end{array}$ & $\begin{array}{l}3.3915^{*} \\
(1.8220)\end{array}$ \\
\hline R-squared & 0.491 & 0.382 & 0.368 & 0.533 & 0.783 & 0.801 \\
\hline Observations & 32,636 & 32,636 & 32,636 & 32,636 & 32,636 & 32,636 \\
\hline $\begin{array}{l}\text { Year dummies and } \\
\text { city-dummies }\end{array}$ & Yes & Yes & Yes & Yes & Yes & Yes \\
\hline $\begin{array}{l}\text { Time-varying city-level } \\
\text { controls }\end{array}$ & No & No & No & No & No & No \\
\hline \multicolumn{7}{|c|}{ Panel B: including city-level time-varying controls } \\
\hline $\begin{array}{l}\text { Enforcement } \\
\text { labor regulations } \\
\text { in city-year }\end{array}$ & $\begin{array}{l}1.5965^{*} \\
(0.9265)\end{array}$ & $\begin{array}{r}-0.2264 \\
(0.6777)\end{array}$ & $\begin{array}{l}1.8229^{*} \\
(0.9309)\end{array}$ & $\begin{array}{l}1.3701 \\
(1.3300)\end{array}$ & $\begin{array}{l}4.8542^{* *} \\
(1.7635)\end{array}$ & $\begin{array}{l}3.0313^{*} \\
(1.5702)\end{array}$ \\
\hline R-squared & 0.503 & 0.394 & 0.379 & 0.543 & 0.790 & 0.806 \\
\hline Observations & 32,540 & 32,540 & 32,540 & 32,540 & 32,540 & 32,540 \\
\hline $\begin{array}{l}\text { Year dummies and } \\
\text { city-dummies }\end{array}$ & Yes & Yes & Yes & Yes & Yes & Yes \\
\hline $\begin{array}{l}\text { Time-varying city-level } \\
\text { controls }\end{array}$ & Yes & Yes & Yes & Yes & Yes & Yes \\
\hline State-year dummies & No & No & No & No & No & No \\
\hline
\end{tabular}

Sources: Authors' calculations using RAIS, Ipeadata, and Ministry of Labor-SFIT administrative data on inspections (1996-2006) Note: this table reports coefficients from the ordinary least squares estimation of Eq. (8) in the paper, where the dependent variable in column (1) is the job creation rate at city-year level, in column (2) job destruction rate at city- year level, in column (3) net growth rate at city-year level (job creation minus job destruction), in column (4) job reallocation rate at city-year level (job creation plus job destruction), in column (5) hiring rates at city-year level, and in column (6) separation rates at the city level. In all specifications, enforcement of labor regulations is measured with the number of inspections per average number of establishments in the city. Panel A does not include city-level time variant controls while panel B includes controls for several observable time-varying city characteristics (unreported) including average, median, and 75th percentile of plant size in the city; city-level GDP; share establishments in agriculture; share of establishments in industry, average, median, and 75th percentile of share of workers with secondary education in the establishment at the city-level; total city population; and total city homicide rates. ${ }^{* *}$ Significance at the $1 \%$ level; ** significance at the $5 \%$ level; * significance at the $10 \%$ level. Robust standard errors, clustered at the city level, are reported in parentheses. All regressions include city-level fixed effects and time dummies. All regressions are weighted by the average employment in the city 
Table 9 Enforcement of labor regulations and job flow rates, controlling for state time trends

\begin{tabular}{lcccccc}
\hline Dependent variable & $\begin{array}{c}\text { Job creation } \\
\text { rate }\end{array}$ & $\begin{array}{c}\text { Job destruction } \\
\text { rate }\end{array}$ & $\begin{array}{c}\text { Net job } \\
\text { growth rate }\end{array}$ & $\begin{array}{c}\text { Job reallocation } \\
\text { rate }\end{array}$ & $\begin{array}{c}\text { Accession } \\
\text { rate }\end{array}$ & $\begin{array}{c}\text { Separation } \\
\text { rate }\end{array}$ \\
& $(1)$ & $(2)$ & $(3)$ & $(4)$ & $(5)$ & $(6)$ \\
\hline Enforcement labor & $1.6148^{*}$ & 0.0168 & $1.5980^{*}$ & 16,317 & $6.2209^{* * *}$ & $4.6229^{* *}$ \\
regulations in city-year & $(0.8837)$ & $(0.6235)$ & $(0.9532)$ & $(1.1961)$ & $(1.6509)$ & $(1.4275)$ \\
R-squared & 0.520 & 0.413 & 0.403 & 0.557 & 0.803 & 0.817 \\
Observations & 32,540 & 32,540 & 32,540 & 32,540 & 32,540 & 32,540 \\
City dummies and & Yes & Yes & Yes & Yes & Yes & Yes \\
time-varying controls & & & & & & Yes \\
State-year dummies & Yes & Yes & Yes & Yes & Yes \\
\hline
\end{tabular}

Sources: Authors' calculations using RAIS, Ipeadata, and Ministry of Labor-SFIT administrative data on inspections (1996-2006) Note: this table reports coefficients from the ordinary least squares estimation of Eq. (9) in the paper, where the dependent variable in column (1) is the job creation rate at city-year level, in column (2) job destruction rate at city- year level, in column (3) net growth rate at city-year level (job creation minus job destruction), in column (4) job reallocation rate at city-year level (job creation plus job destruction), in column (5) accession rates at city-year level, and in column (6) separation rates at the city-level. In all specifications, enforcement of labor regulations is measured with the number of inspections per average number of establishments in the city. Regressions include controls for several observable time-varying city characteristics (unreported) including average, median, and 75th percentile of plant size in the city; city-level GDP; share establishments in agriculture; share of establishments in industry, average, median, and 75th percentile of share of workers with secondary education in the establishment at the city-level; total city population; and total city homicide rates. ${ }^{* *}$ Significance at the $1 \%$ level; ${ }^{*}$ significance at the $5 \%$ level; ${ }^{*}$ significance at the $10 \%$ level. Robust standard errors, clustered at the city level, are reported in parentheses. All regressions include city-level fixed effects and state-year dummies. All regressions are weighted by the average employment in the city

growth, separation, and accession rates. The findings reported in panel B of Table 9 show that an increase of one standard deviation in inspection intensity at the city level is associated with city-level job creation and net growth rates 0.26 percentage points and 0.30 percentage points higher, respectively. The same increase in inspections is associated to accessions and separation rates 0.79 percentage points and 0.49 percentage points higher, respectively. ${ }^{17}$

The positive effect of labor inspections on both margins of worker flows may seem a surprise. However, the main data we exploit, RAIS, only captures formal sector jobs even if the establishment keeps some unregistered workers. Hence, what is computed as accession may represent a worker flow within the establishment from an informal to a formal position. That could explain the positive effect on accessions. The positive effect on separations is interpreted in two ways: firstly, as an employer's reaction aiming cost reduction. Dismissing employees compensates the labor cost increase due to the formalization procedure aforementioned. Secondly, for a given turnover rate, the more formal workers the establishment has, the more separations will be registered at RAIS. This interpretation depends on firms employing part of their workforce under informal contracts. Hence, the magnitude of our results should increase the higher the propensity of firms to hire workers under informal contracts. We will provide some suggestive evidence consistent with this interpretation.

Because the degree of enforcement of labor regulations varies at the city level and over time, it is not possible to account in the reduced form for unobservable city trends. Nevertheless, we acknowledge that there may be trends at a sub-national level, correlated with changes in enforcement (for example, changes in the quality of other institutions at the sub-national level). Hence, we test the robustness of the main specification to the inclusion of state level trends. The main findings are reported in Table 9. ${ }^{18}$ Reassuringly, our main findings are robust to the inclusion of state-time trends. 
As shown in the previous sections, both enforcement levels and labor market flows vary systematically across cities and establishments of different sizes in our sample. To check the robustness of results across these groups, Eq. (8) is estimated separately for different groups of cities depending on their average size, proxied by population and establishment size). Table 10 reports the results for cities with less and more than 10,000 persons in panels A and B, respectively. The coefficients for job creation and worker flows rates reported in columns (1) and (2) remain positive and statistically significant only for small cities suggesting that enforcement of labor regulations produces stronger impacts there. Table 11 has results for cities with average plant size of fewer than 10 employees in panel A and average plant size of 10 or more employees in panel B. Interestingly, results are positive and statistically significant for small average establishments in Table 11 for all job and worker flow rates except in the case of job destruction.

As we have claimed, our estimated effects for labor inspection are more intense for settings with higher incidence of informal labor contracts, such as small municipalities. We interpret the outcome as follows. De jure rules are the same for all cities. But large cities are likely to already face scrutiny by labor inspectors and comply with regulations. Establishments in small cities infringe rules under fewer inspections. Hence, the marginal effect of more enforcement in small cities and establishments is higher, forcing employers to adjust hiring and firing in the face of de facto stringent rules. Since the firm-size distribution in Brazil is left-eschewed, the aggregate results show a positive correlation between flows and inspection frequency.

Table 10 Enforcement of labor regulations and job flow rates, by average population size in the city

\begin{tabular}{|c|c|c|c|c|c|c|}
\hline $\begin{array}{l}\text { Dependent } \\
\text { variable }\end{array}$ & $\begin{array}{l}\text { Job creation } \\
\text { rate } \\
\text { (1) }\end{array}$ & $\begin{array}{l}\text { Job destruction } \\
\text { rate } \\
\text { (2) }\end{array}$ & $\begin{array}{c}\text { Net job } \\
\text { growth rate } \\
\text { (3) }\end{array}$ & $\begin{array}{c}\text { Job reallocation } \\
\text { rate } \\
\text { (4) }\end{array}$ & $\begin{array}{l}\text { Accession } \\
\text { rate } \\
\text { (5) }\end{array}$ & $\begin{array}{l}\text { Separation } \\
\text { rate } \\
\text { (6) }\end{array}$ \\
\hline \multicolumn{7}{|c|}{ Panel A: small cities with less than 10,000 persons } \\
\hline $\begin{array}{l}\text { Enforcement } \\
\text { labor regulations } \\
\text { in city-year }\end{array}$ & $\begin{array}{l}4.0695^{*} \\
(1.9938)\end{array}$ & $\begin{array}{c}-0.6111 \\
(1.2034)\end{array}$ & $\begin{array}{c}4.6806 \\
(2.6136)\end{array}$ & $\begin{array}{c}3.4583 \\
(2.0040)\end{array}$ & $\begin{array}{c}17.8353^{* * *} \\
(4.5676)\end{array}$ & $\begin{array}{c}13.1547^{*} \\
(6.1029)\end{array}$ \\
\hline R-squared & 0.367 & 0.292 & 0.291 & 0.393 & 0.718 & 0.723 \\
\hline Observations & 15,463 & 15,463 & 15,463 & 15,463 & 15,463 & 15,463 \\
\hline $\begin{array}{l}\text { Year and city } \\
\text { dummies }\end{array}$ & Yes & Yes & Yes & Yes & Yes & Yes \\
\hline \multicolumn{7}{|c|}{ Panel B: large cities with more than 10,000 persons } \\
\hline $\begin{array}{l}\text { Enforcement } \\
\text { labor regulations } \\
\text { in city-year }\end{array}$ & $\begin{array}{c}1.3986 \\
(0.9642)\end{array}$ & $\begin{array}{c}-0.2083 \\
(0.7349)\end{array}$ & $\begin{array}{c}1.6069 \\
(0.9887)\end{array}$ & $\begin{array}{c}1.1903 \\
(1.4007)\end{array}$ & $\begin{array}{l}3.6128^{*} \\
(1.7867)\end{array}$ & $\begin{array}{c}20,059 \\
(1.5690)\end{array}$ \\
\hline R-Squared & 0.557 & 0.440 & 0.428 & 0.594 & 0.811 & 0.827 \\
\hline Observations & 17,077 & 17,077 & 17,077 & 17,077 & 17,077 & 17,077 \\
\hline $\begin{array}{l}\text { Year and city } \\
\text { dummies }\end{array}$ & Yes & Yes & Yes & Yes & Yes & Yes \\
\hline
\end{tabular}

Sources: Authors' calculations using RAIS, Ipeadata, and Ministry of Labor-SFIT administrative data on inspections (1996-2006) Note: this table reports coefficients from the ordinary least squares estimation of Eq. (8) in the paper, separately for the sample of cities with population lower than 10,000 persons and higher than 10,000 persons, respectively. The dependent variable differs across regressions. In all specifications, enforcement of labor regulations is measured with the number of inspections per average number of establishments in the city. Regressions include controls for several observable time-varying city characteristics (unreported) including average, median, and 75th percentile of plant size in the city; city-level GDP; share establishments in agriculture; share of establishments in industry, average, median, and 75th percentile of share of workers with secondary education in the establishment at the city-level; total city population; and total city homicide rates. ${ }^{* *}$ Significance at the $1 \%$ level; ${ }^{* *}$ significance at the $5 \%$ level; ${ }^{*}$ significance at the $10 \%$ level 
Table 11 Enforcement of labor regulations and job flow rates, by average plant size in the city

\begin{tabular}{|c|c|c|c|c|c|c|}
\hline $\begin{array}{l}\text { Dependent } \\
\text { variable }\end{array}$ & $\begin{array}{l}\text { Job creation } \\
\text { rate } \\
\text { (1) }\end{array}$ & $\begin{array}{l}\text { Job destruction } \\
\text { rate } \\
\text { (2) }\end{array}$ & $\begin{array}{c}\text { Net job } \\
\text { growth rate } \\
\text { (3) }\end{array}$ & $\begin{array}{l}\text { Job reallocation } \\
\text { rate } \\
\text { (4) }\end{array}$ & $\begin{array}{l}\text { Accession } \\
\text { rate } \\
\text { (5) }\end{array}$ & $\begin{array}{c}\text { Separation } \\
\text { rate } \\
\text { (6) }\end{array}$ \\
\hline \multicolumn{7}{|c|}{ Panel A: cities with a small average plant size } \\
\hline $\begin{array}{l}\text { Enforcement } \\
\text { labor regulations } \\
\text { in city-year }\end{array}$ & $\begin{array}{c}5.1960^{* * *} \\
(1.0522)\end{array}$ & $\begin{array}{l}-0.9681 \\
(0.6984)\end{array}$ & $\begin{array}{c}6.1641^{* * *} \\
(1.3510)\end{array}$ & $\begin{array}{c}4.2279^{* * *} \\
(1.1680)\end{array}$ & $\begin{array}{c}14.4311^{* * *} \\
(1.9822)\end{array}$ & $\begin{array}{c}8.2670^{* * *} \\
(1.7180)\end{array}$ \\
\hline R-squared & 0.487 & 0.396 & 0.392 & 0.525 & 0.788 & 0.807 \\
\hline Observations & 17,892 & 17,892 & 17,892 & 17,892 & 17,892 & 17,892 \\
\hline $\begin{array}{l}\text { Year and city } \\
\text { dummies }\end{array}$ & Yes & Yes & Yes & Yes & Yes & Yes \\
\hline \multicolumn{7}{|c|}{ Panel B: cities with a large average plant size } \\
\hline $\begin{array}{l}\text { Enforcement } \\
\text { labor regulations } \\
\text { in city-year }\end{array}$ & $\begin{array}{c}0.2498 \\
(1.1445)\end{array}$ & $\begin{array}{l}-0.0545 \\
(0.8682)\end{array}$ & $\begin{array}{c}0.3043 \\
(1.1481)\end{array}$ & $\begin{array}{c}0.1953 \\
(1.6760)\end{array}$ & $\begin{array}{c}2.2272 \\
(2.0919)\end{array}$ & $\begin{array}{l}1.9229 \\
(1.8654)\end{array}$ \\
\hline R-squared & 0.544 & 0.425 & 0.451 & 0.556 & 0.834 & 0.843 \\
\hline Observations & 14,648 & 14,648 & 14,648 & 14,648 & 14,648 & 14,648 \\
\hline $\begin{array}{l}\text { Year and city } \\
\text { dummies }\end{array}$ & Yes & Yes & Yes & Yes & Yes & Yes \\
\hline
\end{tabular}

Sources: Authors' calculations using RAIS, Ipeadata, and Ministry of Labor-SFIT administrative data on inspections (1996-2006) Note: this table reports coefficients from the ordinary least squares estimation of Eq. (8) in the paper, separately for the sample of cities with an average small plant size and an average large plant size, respectively. We consider small plant size when the city reports an average plant with less than 10 employees and a large plant size when the city reports an average plant size with more than 10 employees. The dependent variable differs across regressions. In all specifications, enforcement of labor regulations is measured with the number of inspections per average number of establishments in the city. Regressions include controls for several observable time-varying city characteristics (unreported) including average, median, and 75th percentile of plant size in the city; city-level GDP; share establishments in agriculture; share of establishments in industry, average, median, and 75th percentile of share of workers with secondary education in the establishment at the city-level; total city population; and total city homicide rates. ${ }^{* *}$ Significance at the $1 \%$ level; ${ }^{* *}$ significance at the $5 \%$ level; *significance at the $10 \%$ level. Robust standard errors, clustered at the city level, are reported in parentheses. All regressions include city-level fixed effects and time dummies. All regressions are weighted by the average employment in the city

\section{Conclusions}

In this paper, we explore the relationship between the enforcement of labor market regulations and job and worker flow measures. We explore city-level data across Brazilian cities, between 1996 and 2006 to identify whether and how the enforcement of labor regulations is related to different indicators of job and worker flows. The analysis is based on unique city-level and time series administrative data for Brazil, exploring both the census of all plants in Brazil-RAIS-and administrative data on labor inspections. Both data sets are collected by the Brazilian Ministry of Labor and Employment.

Our results suggest that increases in the enforcement of labor market regulations at the city level is strongly correlated with higher job creation rates. This result is also present between labor inspection and net growth, reallocation, and accession and separation rates. The estimations are consistent across samples by city and establishment sizes.

These findings are in line with Almeida and Carneiro (2012). There, the authors find that, in a response to a rise in labor inspections, there is also an increase in formal employment, together with a decrease in informal employment, a rise in non-employment, a decline in wages at the top of the formal wage distribution, and an increase in informal wages. Their argument is that as inspectors started enforcing compliance with mandated benefits, formal workers pay for more generous mandated benefits by receiving lower wages. The value that workers place on these benefits is potentially higher 
than their cost to employers because they are untaxed. In addition, wage rigidity (e.g., through minimum wages) prevents downward adjustment at the bottom of the wage distribution. This causes formal sector jobs at the bottom of the wage distribution, to become more attractive to informal workers, leading them to switch to the formal sector. In the process, wages in the informal sector adjust upwards.

\section{Endnotes}

${ }^{1}$ The emphasis on flows as opposed to stocks motivated the terminology "flow approach" to the labor market as referred by Blanchard and Portugal (2001) and others since then.

${ }^{2}$ Examples include Haltiwanger et al. (2010), Bartelsman et al. (2009), and Bocconi et al. (2008)

${ }^{3}$ Data from IPEADATA.gov. Informality is defined as the ratio of self-employed plus unregistered workers divided by the sum of employers, self-employed, registered, and unregistered workers in the labor market.

${ }^{4}$ Inspections cover a wide range of mandated benefits and rules including social security and unemployment insurance contributions, maximum working hours, registration cards, minimum wage compliance, and subsidies for commuting and transportation expenses.

${ }^{5}$ The literature on the effects of mandated benefits on labor market outcomes in developing countries has produced mixed results. The question of whether benefits impact employment and wages remains only partially answered, since different authors have found both increases and reductions in employment and wages after relevant labor market reforms. Take the case of two studies on social security in Latin American which showed opposite answers. Gruber (1997) analyzes the social security reforms in Chile in the eighties which sharply reduced payroll taxes. The results point to wage shifting following lower taxes and little employment effects, regardless of the choice of estimation technique. Closer to our work, Kugler and Kugler (2002) use a panel of manufacturing firms in Colombia to assess wage and employment outcomes after a government attempt to improve Social Security funding with higher payroll taxes. Using variation in tax rates and compliance between firms and industries, the authors find that the adjustment happened largely through unemployment instead of wages.

${ }^{6}$ Employment protection rules may vary for different types of workers and firms, hence their potential to generate misallocation and change the optimal choice of labor input and firm size. One example can be found in Kugler and Pica (2008) study of the impact of an increase in employment protection costs for small firms in Italy. Difference-in-difference exercises for a regulation change in 1990 indicate that higher firing costs lowered turnover rates of small firms. Small businesses were also less likely to enter the market after the reform. Employment protection can also affect the pace of worker flows. In the case of Chile, Montenegro and Pages (2004) estimate the effect of severance payment in job loss and job finding rates of different workers. Employees with shorter tenure bring lower dismissal costs. This is the case of young and female workers who display higher chances of dismissal over the cycle and higher job finding rates.

${ }^{7}$ Almeida and Carneiro (2009) explore firm-level data from the Brazil World Bank's Enterprise surveys to relate a more stringent enforcement of labor market regulations with the number of hires and fires among formal firms. The results suggest that, on average, firms facing an increased probability of being inspected (by 1 percentage point) 
employ $0.38 \%$ less workers than similar firms. They suggest that more intensive inspection inhibit the use of informal hires and impose a cost on firms decreasing the level of new formal hires. It is worth stressing, however, that their data also cannot identify whether workers have a formalized work contract. It is possible that the registration of a worker who has already been employed, albeit informally, may not be accounted for as a hire. This may lead to an underestimation of the impacts of labor inspections on total employment.

${ }^{8}$ The government's concern with reducing the fiscal deficit at this time is pointed as a strong motivation to pursue an increase in the efficacy of labor inspection. One of the items commonly inspected are the deposits in the FGTS. Cardoso and Lage (2007), for example, encourage the reader to make this association.

${ }^{9}$ The author also suggests that a collective mechanism can be more effective than a bonus mechanism.

${ }^{10}$ The author also points to the relevance of an integrated performance of the inspection with other public agents, such as SEBRAI, state secretaries, and the public state ministry. This appears to bring synergies by virtue of the fact that such agents have similar objectives with respect to combating informality, understood in a broader sense.

${ }^{11}$ Cardoso and Lage (2007) report that labor inspections started to focus on large firms, attributing this behavior to the incentives given to inspectors, who would rather visit larger firms.

${ }^{12}$ It is often argued that labor fines may have their efficacy diminished in Brazil given the limited reach of Labor Courts in the country. See Magalhães (2010).

${ }^{13}$ SFIT data show that the improvement in the performance of labor inspections is not limited to the regularization of workers. For example, the percentage of irregularities solved out of total irregularities found during inspections rose $71.1 \%$ from 1996 to 2000 and $84.5 \%$ from 2001 to 2006.

${ }^{14}$ This data is adequate for our analysis as it includes establishments/plants of all sizes as long as they are formally registered. This contrasts with some firm level data for selected developing countries which only capture firms employing more than a threshold level.

${ }^{15}$ In the text, we use interchangeably the terms plant and establishment, since they both refer to the unit of observation available in the data..

${ }^{16}$ This information is available at http://www.ipeadata.gov.br, while population and homicides information are available at http://www.datasus.gov.br.

${ }^{17}$ The back-of-the-envelope calculations multiply the standard deviation of the inspection intensity explanatory variable $(0.16)$ by the coefficients of interest in panel B of Table 8.

${ }^{18}$ There is a total of 27 states in Brazil, and we exploit data for 6 years, for a total of 162 state trends.

\section{Appendix}

\section{Non-compatibility between RAIS and SFIT in the case of new cities}

After the 1988 Constitution, there was a spur in creation of new cities in Brazil. This phenomenon was concentrated in the early 1990s but one can still observe new cities in the sample starting in 1996. This raises the issue that SFIT and RAIS do not incorporate new city codes into the data set at the same time. While SFIT includes the new 
city in the year it is created, RAIS only registers it in the following year. The mismatch creates a few problematic cases when merging the two data sets. In order to keep the information from the year when a new city is created, we proceed as follows:

i) Identify city codes appearing in SFIT but not in RAIS in each year.

ii) Check if the code appearing only at SFIT in a specific year can be found at RAIS in the following year.

iii) If a code follows cases 1 and 2 above, identify the group of firms with the new city code.

iv) Identify in 3 the sub-group of firms appearing at RAIS in the previous year.

v) Impute the new city codes to the information from the labor inspection database.

\section{Acknowledgements}

We gratefully acknowledge suggestions made by seminar participants at IPEA (2012), the 2011 meeting of the Brazilian Economic Association, and the conference Reforming Minimum Wage and Labor Regulation Policy in Developing and Transition Economies held at the Beijing Normal University (2014). We are very grateful for the Ministerio Trabalho e Emprego for sharing the data on labor inspections.

We would also like to thank the anonymous referee and the editor for the useful remarks.

Responsible editor: David Lam

Funding

Ana Abras thanks the Fundação de Amparo à Pesquisa de São Paulo (FAPESP) for the Post-Doctoral Fellowship under which part of the work was undertaken.

\section{Competing interests}

The IZA Journal of Development and Migration is committed to the IZA Guiding Principles of Research Integrity. The authors declare that they have observed these principles.

\section{Publisher's Note}

Springer Nature remains neutral with regard to jurisdictional claims in published maps and institutional affiliations.

\section{Author details}

'Universidade Federal do ABC, Rua Arcturus 3, São Bernardo do Campo, São Paulo 09606-070, Brazil. "World Bank, 1818 H Street, NW, Washington, D.C. 20433, USA. ${ }^{3}$ University College London, Gower Street, London WC1E 6BT, UK.

${ }^{4}$ Instituto de Pesquisa Econômica Aplicada, Av. Pres. Antônio Carlos, 51, Centro, Rio de Janeiro, RJ 20020-010, Brazil.

Received: 13 March 2018 Accepted: 12 April 2018

Published online: 13 November 2018

\section{References}

Almeida, M. Além da Informalidade: Entendendo Como os Fiscais e Agentes de Desenvolvimento Promovem a Formalização o Crescimento de Pequenas e Médias Empresas. Ipea (Texto para Discussão, 2008 n. 1.353). Almeida R, Carneiro P. Enforcement of labor regulation and firm size. J Comp Econ. 2009:37:28-46.

Almeida R, Carneiro P. Enforcement of labor regulation and informality. Am Econ J Appl Econ. 2012;4(3)

Bartelsman, E, J Haltiwanger; and S Scarpetta Measuring and analyzing cross country differences in firm dynamics, in Producer dynamics: new evidence from micro data, (Dunne, Jensen and Roberts, eds.) NBER/University of Chicago Press, 2009.

Bertola G, Rogerson R. Institutions and labor reallocation. European Econ Review. 1997;41(6):1147-71.

Blanchard O, Portugal P. What hides behind an unemployment rate: comparing Portuguese and U.S. labor markets. Am Econ Review. 2001;91(1):187-207.

Bocconi, Tito Boeri; Helppie, Brook; Mario Macis (2008). Labor regulations in developing countries: a review of the evidence and directions for future research. World Bank, Social Protection Discussion Paper 0833.

Brochu P, Green D. The impact of minimum wages on labor market transitions. Economic J. 2013;123:1203-35.

Cardoso, A., Lage, T. As Normas e os Fatos. Editora FGV, Rio de Janeiro, Brasil. 2007

Catão, L.; Pages, C. and Rosales. Financial dependence, formal credit and informal jobs: new evidence from Brazilian household data. RES working papers 4642, Inter-American Development Bank, Research Department. 2009

Davis, S; Haltiwanger, J; and Schuh, S Job Creation and Destruction. MIT Press. 1996

Davis, S and Haltiwanger, J. Gross job flows, in handbook of labor economics, volume 3, North-Holland 1999

Fajnzylber P, Maloney WF, Montes-Rojas GV. Does formality improve micro-firm performance? Evidence from the Brazilian SIMPLES program. J Dev Eco. 2011;94(2):262-76.

Gruber J. The incidence of payroll taxation: evidence from Chile. J Labor Econ. 1997;15(3):S72-S100.

Haltiwanger, J; Scarpetta, S; and Schweiger, H. Cross country differences in job reallocation: the role of industry, firm size and regulations. European Bank for Reconstruction and Development. WP 2010116.

Hyatt H, Spletzer J. The recent decline in employment dynamics. IZA J Labor. 2013;2013:3-5. 
Kugler, A and Kugler, M. Effects of payroll taxes on employment and wages: evidence from the Columbian social security reform. Center for Research on Economic Development and Policy Reform, Working Paper No. 2002134 Kugler A, Pica G. Effects of employment protection on job and worker flows: evidence from the 1990 Italian reform. Labour Econ. 2008;15(1):78-95.

Magalhães, H. La inspección (o no) del trabajo y las sanciones (o no) por incumplimiento de la legislación laboral en Brasil, mimeo 2010.

Micco, A and C Pages. Employment protection and gross job flows: a difference-in-difference approach. Inter-American Development Bank, Research Department 2004.

Miguel A. A Inspeção do Trabalho no Governo FHC: Análise sobre a Política de Fiscalização do Trabalho. Dissertação de mestrado, Programa de Pós-Graduação em Ciências Sociais. São Carlos: Universidade Federal de São Carlos; 2004.

Montenegro; and Pages, C. Who benefits from labor market regulation? Chile 1960-1998. NBER Working Paper No 08502004.

Pires R. Promoting sustainable compliance: styles of labour inspection and compliance outcomes in Brazil. Int Labour Review. 2008;147:199-249.

Pires, R. Beyond the fear of discretion: flexibility, performance, and accountability in the management of regulatory bureaucracies. Reg Govern. 2011:5:43-69.

Shimer, R. Reassessing the Ins and Outs of Unemployment. Review of Economic Dynamics, 2012;15(2):127-148.

Submit your manuscript to a SpringerOpen ${ }^{\circ}$ journal and benefit from:

- Convenient online submission

- Rigorous peer review

- Open access: articles freely available online

- High visibility within the field

- Retaining the copyright to your article

Submit your next manuscript at $>$ springeropen.com 